\title{
Organizational Attention Deficit as Sustainability Indicator: Assessment and Management
}

\author{
Article history \\ Received: 25 September 2013 \\ Sent for revision: 17 October 2013 \\ Received in revised form: 25 November 2013 \\ Accepted: 27 November 2013 \\ Available online: 6 December 2013
}

\begin{abstract}
The aim of this paper is to contribute towards dealing with the attention indicator in a standard Pressure-State-Response (PSR) framework of sustainable development. Hence, the daily information overflow is identified as a pressure variable adversely affecting the attention. This is manifested by an increased likelihood of missing key information when making decisions, diminished time for attentive reflection, difficulty in holding others' attention, as well as by decreased ability to focus when necessary, which are symptoms of the so-called organizational attention deficit disorder - OADD. As to the state variable there were combined techniques from cognitive neuroscience and applied sciences in order to objectively measure the incidence of OADD. In particular, the use of neuropsychological procedures for objective assessment of OADD will be summarized. Namely, few attention diagnostic tests of the Amsterdam Neuropsychological Tasks Program (ANT) will be considered for determining the focused, shifted and sustained attention. As intervention measure attention strengthening techniques is applied. In particular, in research were proposed the neurofeedback technique as response variable and have shown its effectiveness in coping with the OADD. This approach represents a new perspective in social psychophysiology and expands the potential applications of ANT and neurofeedback methodology.
\end{abstract}

\footnotetext{
${ }^{1}$ Macedonian Academy of Sciences and Arts, Skopje, Republic of Macedonia, silvana@manu.edu.mk

${ }^{2}$ Macedonian Academy of Sciences and Arts, Skopje, Republic of Macedonia, ipj@manu.edu.mk

${ }^{3}$ Macedonian Academy of Sciences and Arts, Skopje, Republic of Macedonia, popjordanova.nadica@gmail.com

${ }^{4}$ Macedonian Academy of Sciences and Arts, Skopje, Republic of Macedonia, natasa@manu.edu.mk
} 
Markovska Simoska S. et al.: Organizational attention deficit as sustainability...

Keywords: sustainable development, mind indicators, organizational attention deficit, neuropsychological testing, neurofeedback.

\section{Deficit organizacijske pažnje kao indikator održivosti - procena i upravljanje}

Apstrakt: Ovaj rad ima za cilj da doprinese održivom razvoju primenom indikatora pažnje standardnog Pritisak-Stanje-Odgovor (PSR) okvira. Svaki priliv informacija je identifikovan kao varijabla pritiska koja negativno deluje na pažnju. Sve to se manifestuje preko povišenog gubitka ključnjih informacija u trenutku donošenja odluka i smanjenja sposobnosti fokusiranja kada je to neophodno, što su bitni simptomi tzv. „poremećaja deficit organizaciske paznje" (OADD). Kako bi se objektivnije merila incidencija OADD, $u$ istraživanju su kombinovane tehnike pozajmljene iz kognitivne neuronauke $i$ primenjenih nauka. Posebno, sumirano su predstavljene korišćene neuropsihološke procedure za objektivno procenjivanje OADD. Neki delovi dijagnostičkih testova u sklopu Amsterdamovog Neuropsiholoskog Programa (ANT) za ispitivanje pažnje korišćeni su za determiniranje fokusirane, održive $i$ promenjive pažnje. U cilju poboljšanja pažnje predložene su posebne tehnike. $U$ istraživanju je korišćena neurofidbek metoda kao varijabla odgovora, čija je efikasnost dokazana u sprovođenju OADD metode. Ovakav prilaz nudi sasvim novu perspektivu u socijalnoj neuropsihologiji $i$ proširuje područje korišćenja ANT-a i neurofidbek metodologije.

Ključne reči: održiv razvoj, mentalni indikatori, deficit organizaciske pažnje, neuropsiholosko testiranje, neurofidbek.

\section{Introduction}

Indicators of Sustainable Development (ISD) are quantifiable parameters to measure progress and monitor changes (progress or degradation), signal alarms and define challenges towards sustainability (National Research Council, 1999). The current sets of ISD, accepted worldwide, are built upon the PressureState-Response (PSR) framework (presented in Fig.1) and reflect the assessment of the three dimensions of sustainable development - economic, environmental and social (IAEA-IEA, 2001). The current indicators are accountable for material and energy resources and their impacts, without concerns on mental resources and capacities. Occupational or mental entropy therefore, is the newly introduced concept (Pop-Jordanov, 2003; Pop-Jordanov et al., 2004) addressing the disorders and degradation caused by mind agents: a) cognitive: information overflow; b) emotional: occupational stress and c) moral: corruption pressure. 
Markovska Simoska S. et al.: Organizational attention deficit as sustainability...

Figure 1. PSR framework for indicators of sustainable development

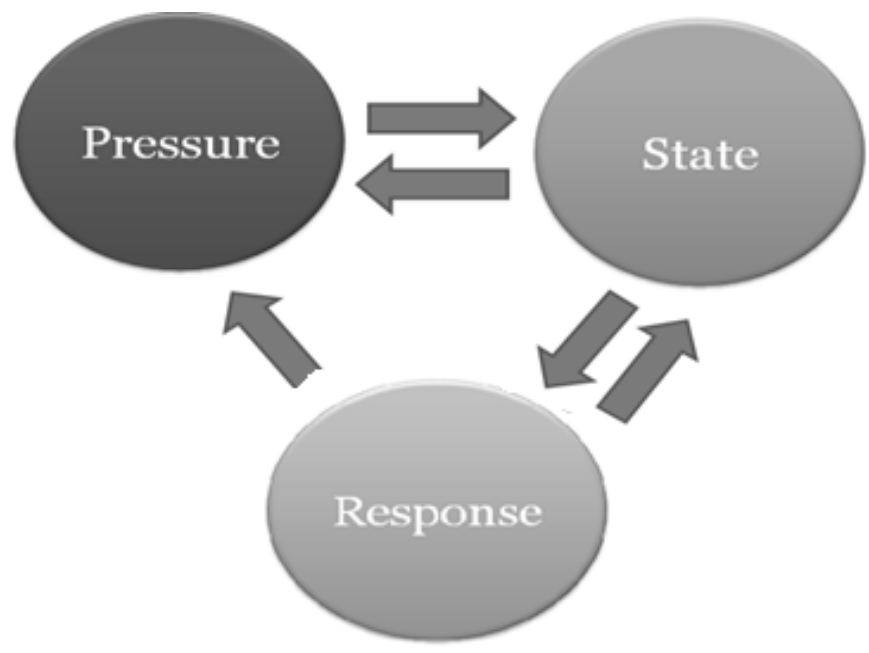

Source: Author

Today, we are focused on knowledge based economy (society) where attention is a vital component of mental capacities, analyzing its role as a psychophysiological - mind ISD. The aim of this paper is to contribute towards dealing with this gap by analyzing the attention indicator in a standard PSR framework.

\subsection{Pressure}

In today's information society flooded world, the scarcest resource is not ideas: it is attention. Hence, the daily information overflow is identified as a pressure variable adversely affecting the attention. Over the past several decades, especially with the advent of internet, we have witnessed information revolution. We are all overcrowded with the information that we could ever deal with: computerized (high information overload with the click of a mouse) and noncomputerized (phone calls, faxes, paper mail). This is manifested by an increased likelihood of missing key information when making decisions, diminished time for attentive reflection, difficulty in holding others' attention, as well as by decreased ability to focus when necessary, which are symptoms of the so-called organizational attention deficit disorder - OADD (Davenport \& Beck, 2001). Also, the last few years attention deficit disorder (ADD) is diagnosed with increasing frequency in adults (4-6\% of adult population) (Barkley, 1998).

The corresponding indicators in PSR representation are displayed in Fig.2. 
Markovska Simoska S. et al.: Organizational attention deficit as sustainability...

Figure 2. OADD indicators in PSR framework

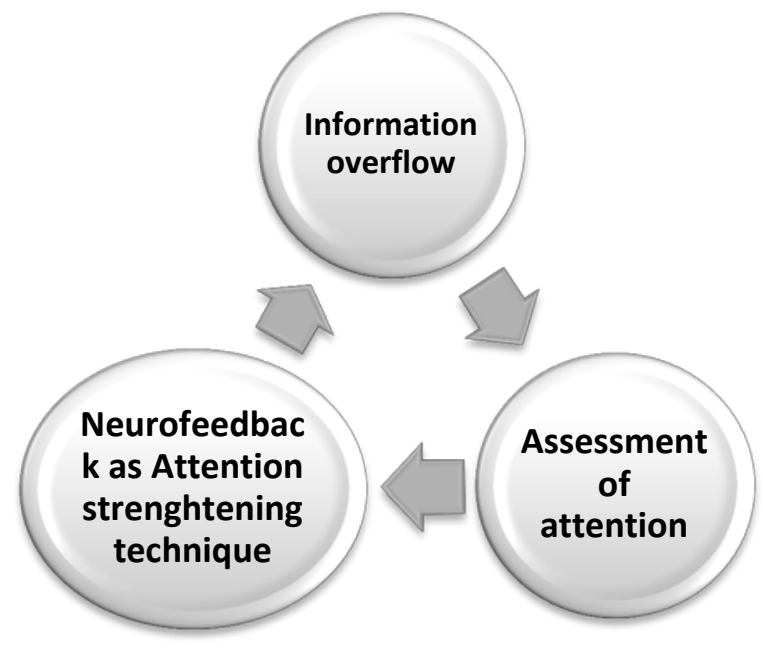

Source:Author

\subsection{State}

Previously, we had a practical research activities focused on testing e-learning indicators: e-content and attention as well as their interrelated correlation. We propose this methodology and measurements to be realized in order to evaluate the effectiveness of an e-learning system and find out the correlation of econtent and attention curve for each particular system (Fetaji et al., 2007).

In order to assess the state of the PSR framework and to objectively measure attention, we need a working definition of attention. From neurophysiological point of view, attention is a cognitive mechanism that enables one to process a selected source of sensory information in more detail in comparison to unselected sources by means of limited resources of the brain processor (Kropotov, 2009). Attention could be also defined as a state of readiness to receive a certain stimulus - that is, a state for looking forward for a sensory event. In this definition, attention must be separated from motor preparatory set as a state of readiness to make a movement. Also, it can be defined as limitation system of processing information in the working memory (control system). The limitation can occur with a divided or focused strategy.

The following types of attention are recognized: 
Markovska Simoska S. et al.: Organizational attention deficit as sustainability...

- Divided attention is ability to pay attention to different cognitive tasks simultaneously. Deficit in divided attention is presented as slowing in information processing.

- Focused attention means ability to consider the relevant information and to ignore the irrelevant stimuli. Deficits in it are expressed in longer time to analyze the distractors.

- Sustained attention is ability to maintain a constant level of performance in time. This deficit will give variability of performance in time and less accuracy.

Since attention affects subject's performances, the development of a specific task for its measurement is crucial and depends from the considered model.

\subsection{Response}

However understanding and managing attention is considered as very important determinant of successful learning. As intervention measure we applied the neurofeedback as attention strengthening technique.

Biofeedback is a self-control method, based on electronic measuring and feeding back of information about one's own inner activity. In particular, we have proposed the neurofeedback technique as response variable and have shown its effectiveness in coping with the OADD. Neurofeedback (NF) or attention training is an operant conditioning procedure whereby an individual modifies the amplitude, frequency, or coherency of the electrophysiological dynamics of his/her own brain (Pop-Jordanova et al., 2005). It involves teaching skills through the rewarding experience of inducing changes in a perceivable signal (light or sound).

\section{Research methodology}

For this aim we used attention diagnostic tests from the Amsterdam Neuropsychological Tasks Program (ANT). ANT is a battery of neuropsychological tests (ANT 4.0), (De Soneville, 1999), that allows systematic evaluation of information processing capacities. Measured and analyzed parameters are speed, speed variability and accuracy of performance. We also measure a social adaptability by applying the ANT tasks for identification of facial emotions as well as face recognition.

For the purpose of this paper we examined 50 subjects who complained on the symptoms of OADD (26 males, 24 females, mean age $=33.4 ; \mathrm{SD}=8.39$ ) and 50 controls who did not complained on OADD symptoms ( 25 males, 25 females, mean age $=32.8 ; \mathrm{SD}=8.22$ ). There were no statistically significant differences 
Markovska Simoska S. et al.: Organizational attention deficit as sustainability...

of age between the two groups. Set of interviews and questionnaires was used to confirm or exclude symptoms of OADD.

All the tasks have two or three conditions of increasing difficulty: their comparison highlights the function of the stage under examination. All the tasks are organized in such a way to evaluate divided, focused and sustained attention in the four processing stages separately: encoding, memory search, decision and response organization. Stimuli and tasks are age-appropriate by selectively using abstract and concrete pictures, letters and spatial patterns for stimuli. The particular assessment included ten tasks from the ANT program. The measures used for the present study were part of a series of studies investigating aspects of neuropsychological and neurophysiological functioning among subjects with and without OADD. Of the ten ANT tasks, only six that were suitable for the topic of this paper were analyzed. The subjects were seated at a table at a distance of 1 to $1.5 \mathrm{~m}$ from the computer screen. All the participants signed the inform consent. The applied tasks were:

Focused attention 4 letters task (FA4L). In this task 4 letters are displayed on the screen with target letter location (relevant vs. irrelevant) and letter type (target letter vs. nontarget letters). The task is consisted of two parts. In the first part only one letter is memorized and should be recognized, while in the second part there are three target letters that should be found. The most important is selective attending of relevant diagonal and inhibition of response to irrelevant target letter.

GoNoGo (GNG). Is a continuous performance test with central presentation of Go and NoGo signals. Measure of inattention and inhibition of prepotent responses.

Shifting Set Visual (SSV). This task assesses attentional flexibility, an aspect of executive functioning. A colored square jumps randomly on a horizontal bar to the right or left. Depending on the color of the square right after the jump, the subject has to execute a compatible response (press the key towards which the jump was directed) or an incompatible response ('mirror' movement; press the right key when the jump was to the left and vice versa). This test consists of three parts. During the first two parts of the task the color is constant (fixed stimulus response mapping), but in the third part the color varies, requiring attentional flexibility by continuously having to adjust response type.

Sustained Attention Dots (SAD). The subject has to discriminate between patterns containing three, four or five dots, presented in 50 series of 12 signals each. Probability of yes vs. no response $=1: 2$. As a consequence, with time-ontask a response bias (for the no-response key) is induced. Fluctuation in speed of processing during time on the task is considered the most important outcome measure. 
Markovska Simoska S. et al.: Organizational attention deficit as sustainability...

Face Recognition (FR). The subject had to discover a target face in a display set that consisted of four faces. Both the target face and the faces in the display set were four digitized high-quality color photos of human faces ("frontal," "profile" and "upside-down," neutral expression). Recognition of unfamiliar faces with varied mapping condition i.e. short term memory for social information is the main parameter obtained with this task.

Identification of Facial Emotions (IFE). In this task the subject is asked to decide whether a face shows a specific ("target") expression ("yes" key) or an expression different from that one ("no" key). The signal consists of one digitized photo of a face showing an expression that can be identified as happy, sad, angry, or afraid.

Each task of the battery is organized in such a way that the performance of an individual is measured through the following attentional parameters: a) reaction time (marker for information processing - is the result of time spent during such mental processes - processing speed), b) variation of the reaction time - fluctuation in time (marker of variation of attention), c) accuracy - omission errors (index of inattention) and d) distraction - commission errors (marker of impulsivity).

\section{Results and discussion}

The results suggest that specific information processing deficits are present in OADD (slower reaction time, greater fluctuation of reaction time and significant difference in error types) during neuropsychological assessment. Indeed, investigations of the incidence of OADD have indicated that they should not be neglected (Fig. 3-11, Table 1). Namely, for both investigated groups there is a considerable difference between the normal controls and adults with OADD, illustrating the attention deficit symptoms.

On Fig. 3 the reaction times for FA4L task are presented. As can be seen from the figure, the reaction times of OADD group in the second part of the task (which is more attention demanding concerning the memory of more letters) are significantly longer than the reaction times of norms without OADD. These means that OADD adults need significantly longer time to recognize the target letters. 
Markovska Simoska S. et al.: Organizational attention deficit as sustainability...

Figure 3. Reaction times (RTS) for the FA4L task

(Th - RT hits; Tcit - RT correct rejection irrelevant targets; Tcrn - RT correct rejection relevant nontargets; 1 - first part of the task; 2 - second part of the task; ${ }^{*} p<0.05$ )

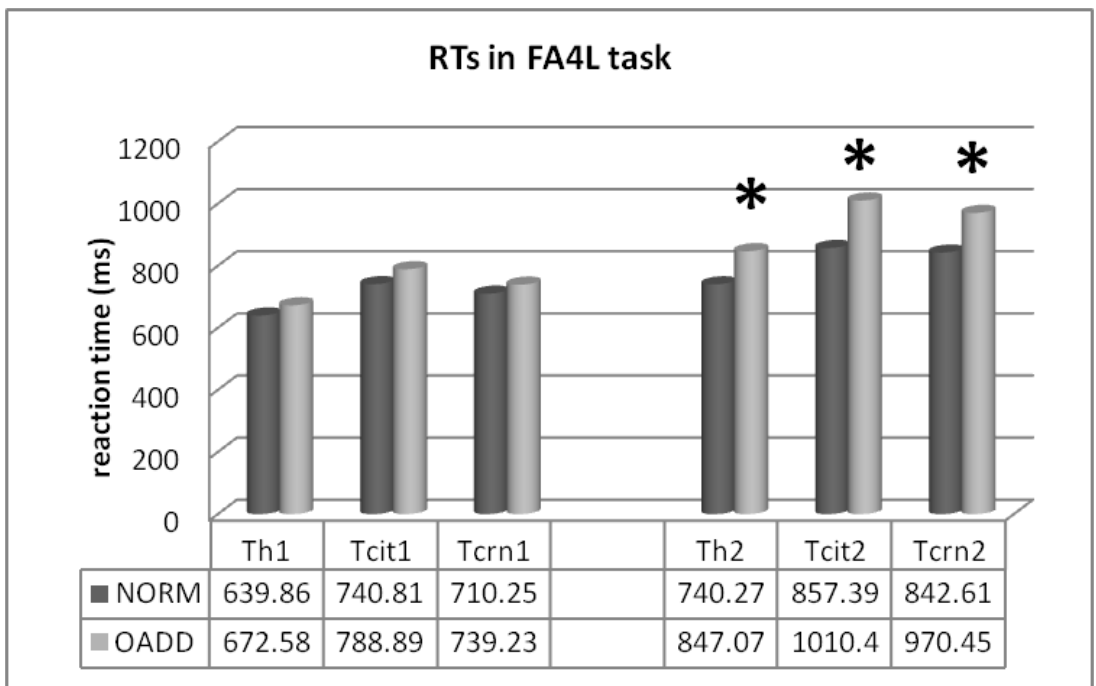

Source:Author

Standard deviation of the reaction time (variation of reaction time) is an indirect indicator of inattention. So, on Fig. 4 are shown the variations of reaction times for FA4L task. It can be noted that the variation of reaction times is significantly higher for both parts of the task (easy and difficult part) giving the objective parameter of existence of huge variation of attention while completing the task in OADD group. 
Markovska Simoska S. et al.: Organizational attention deficit as sustainability...

Figure 4. Standard deviation (SD) of reaction time for the FA4L task (Sh - SD RT hits; Scit - SD RT correct rejection irrelevant targets; Scrn - SD RT correct rejection relevant nontargets; 1 - first part of the task; 2 - second part of the task; $\left.{ }^{*} p<0.05\right)$

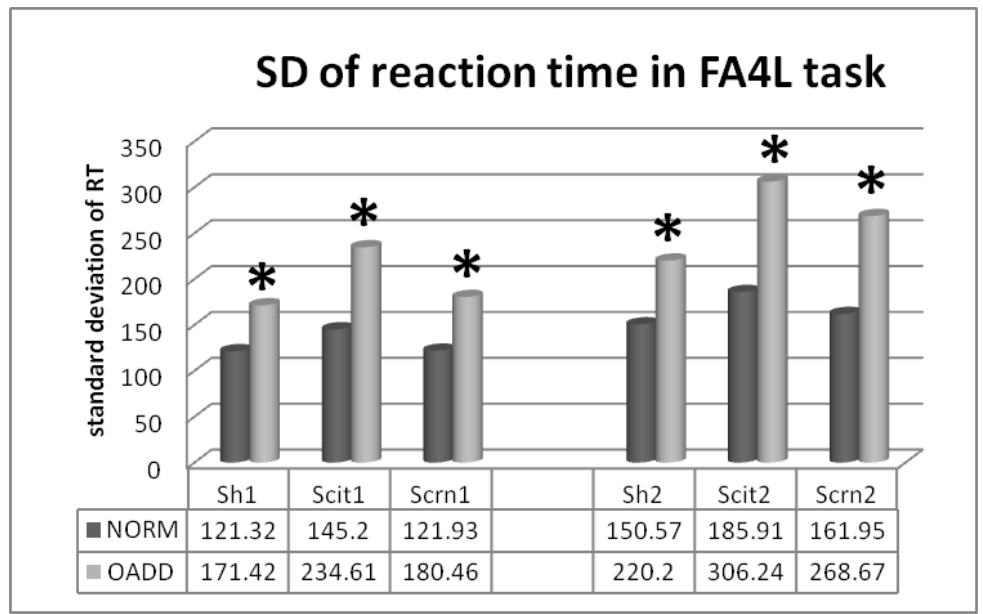

Source:Author

Figure 5. Reaction time for all three parts of the SSV task (compatible and incompatible - left and right) (cl - compatible left; $\mathrm{cr}$ - compatible right; il incompatible left; ir - incompatible right; 1 - first part; 2 - second part; 3 - third part, $\left.{ }^{*} p<0.05\right)$

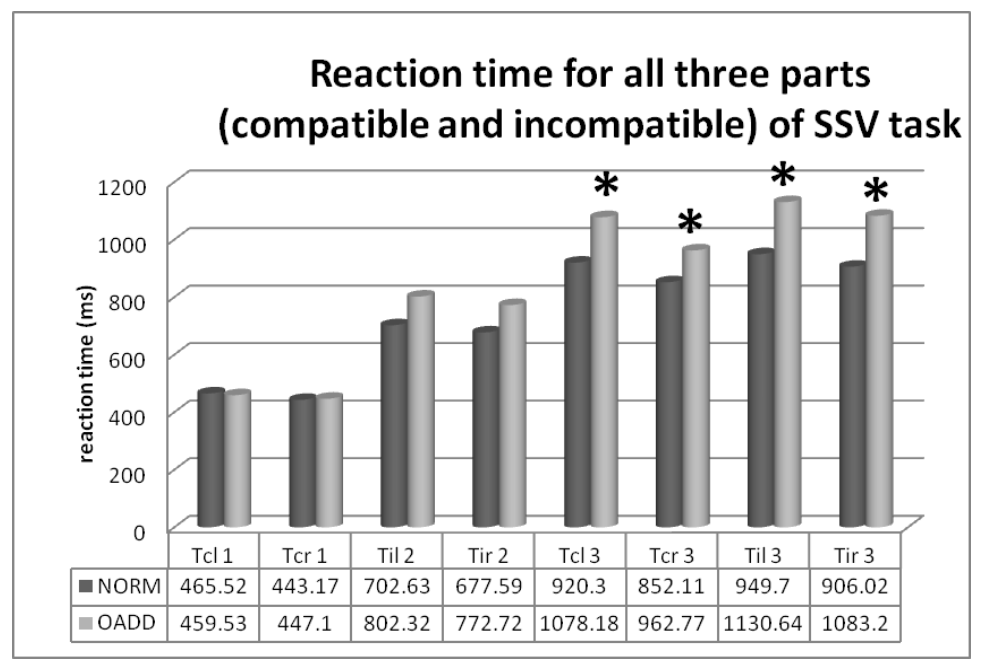

Source:Author

Industrija, Vol.41, No.4, 2013 
Markovska Simoska S. et al.: Organizational attention deficit as sustainability...

For the reaction time during SSV task (Fig.5), the same principle is valid as for the FA4L task. Namely, during the third part of the task (the most difficult one) reaction time for all types of stimuli is significantly longer in OADD group compared to normal group.

Also, there is higher variation for the reaction time in OADD group versus norms during SSV task, indicating the significant variation of attention while completing the task (Fig.6).

Figure 6. Standard deviation of reaction time for all three parts of the SSV task (compatible and incompatible - left and right) (cl - compatible left; $\mathrm{cr}$ compatible right; il - incompatible left; ir - incompatible right; 1 - first part; 2 second part; 3 - third part, ${ }^{*} p<0.05$ )

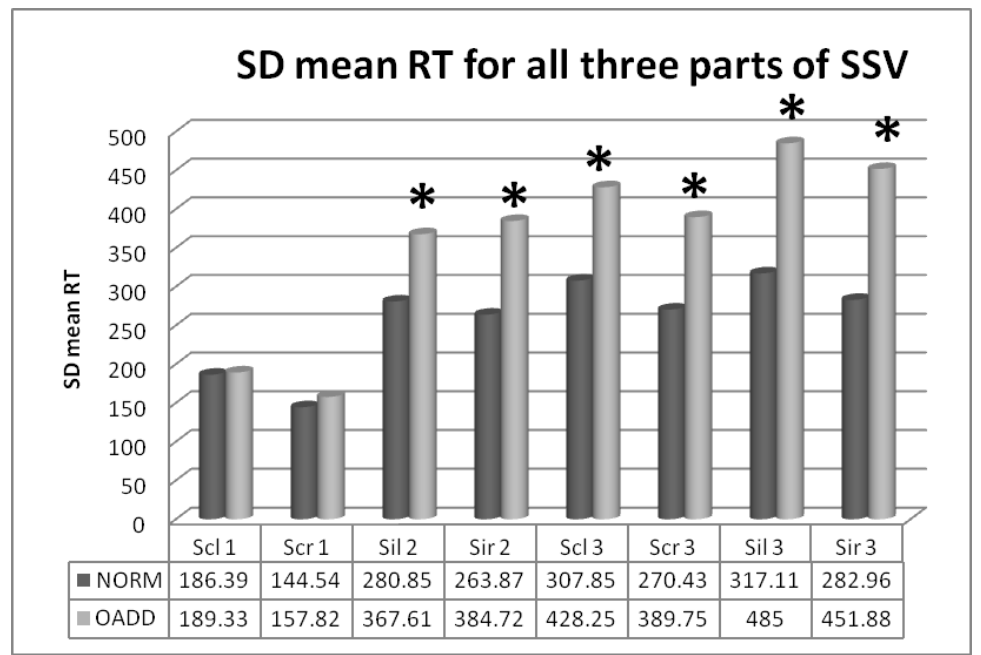

Source:Author

The OADD group showed a greater response time and larger variability of reaction time than the control group, and a significant difference in error types during GoNoGo task (Table 1). 
Markovska Simoska S. et al.: Organizational attention deficit as sustainability...

Table 1. Behavioral parameters in GoNoGo task $\left.{ }^{\star \star \star} p<0.001 ;{ }^{* \star} p<0.01\right)$

\begin{tabular}{lcccc}
\hline & Controls & $S D$ & OADD & $S D$ \\
\hline Omission errors & 1.40 & $(1.62)$ & $13.85^{\star \star \star}$ & $(2.98)$ \\
Reaction time(ms) & 364.63 & $(54.67)$ & $457.07^{\star \star \star}$ & $(72.26)$ \\
$\begin{array}{l}\text { Standard deviation of } \\
\text { the reaction time }\end{array}$ & 7.22 & $(2.265)$ & $13.9^{\star \star *}$ & $(3.20)$ \\
Commission errors & 0.69 & $(1.28)$ & $2.31^{\star \star}$ & $(1.46)$ \\
\hline
\end{tabular}

Source: Author

Also, there was high variability in sustained attention for OADD during 20 minutes duration of a SAD task (Fig.7).

Figure 7. SD of mean RT during the SAD task.

(Sh -SD mean RT hits, Scl-SD mean RT low dots; Sch - SD mean

$R T$ high dots, ${ }^{*} p<0.05$ )

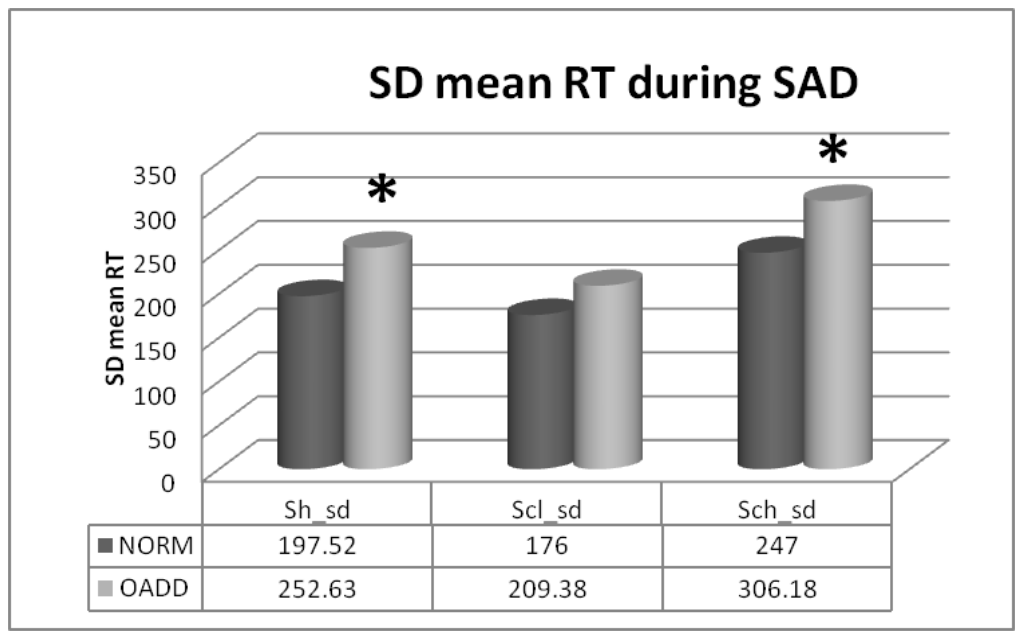

Source: Author

The results suggest that specific information processing deficits are present in OADD adults (slower reaction time and greater fluctuation of reaction time) during face recognition and identification and matching of facial emotions tasks (Fig. 8-11). Response speed variability yielded the most significant differences between OADD adults and the control group. 
Markovska Simoska S. et al.: Organizational attention deficit as sustainability...

Figure 8. Reaction time in the face recognition task for frontal, profile and upside-down faces as a function of group type

( $H$ - hits; CR - correct rejections; fr - frontal; pr - profile; ud - upside-down faces; $H=$ hits, $C R=$ correct rejections, ${ }^{*} p<0.05$ )

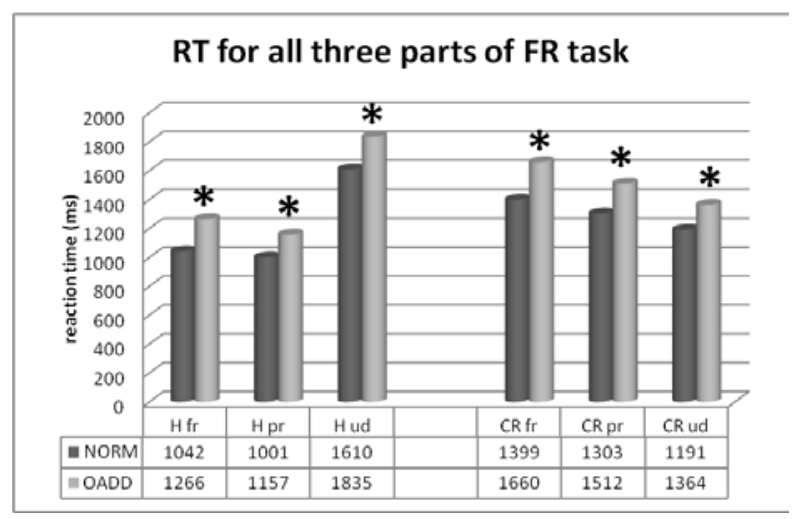

Source: Author

Figure 9. Variation of reaction time in the face recognition task for frontal, profile and upside-down faces

( $H$ - hits; CR - correct rejections; fr - frontal; pr - profile; ud - upside-down faces; $H=$ hits, $C R=$ correct rejections, ${ }^{*} p<0.05$ )

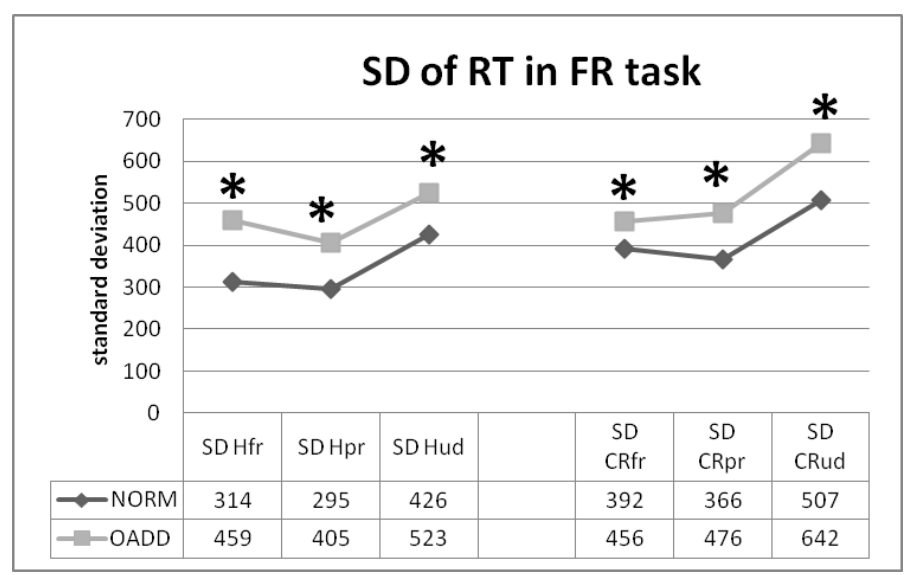

Source: Author 
Markovska Simoska S. et al.: Organizational attention deficit as sustainability...

Figure 10. Reaction time during IFE ( $H=$ hits, $C R=$ correct rejections, $\left.{ }^{\star} p<0.05\right)$

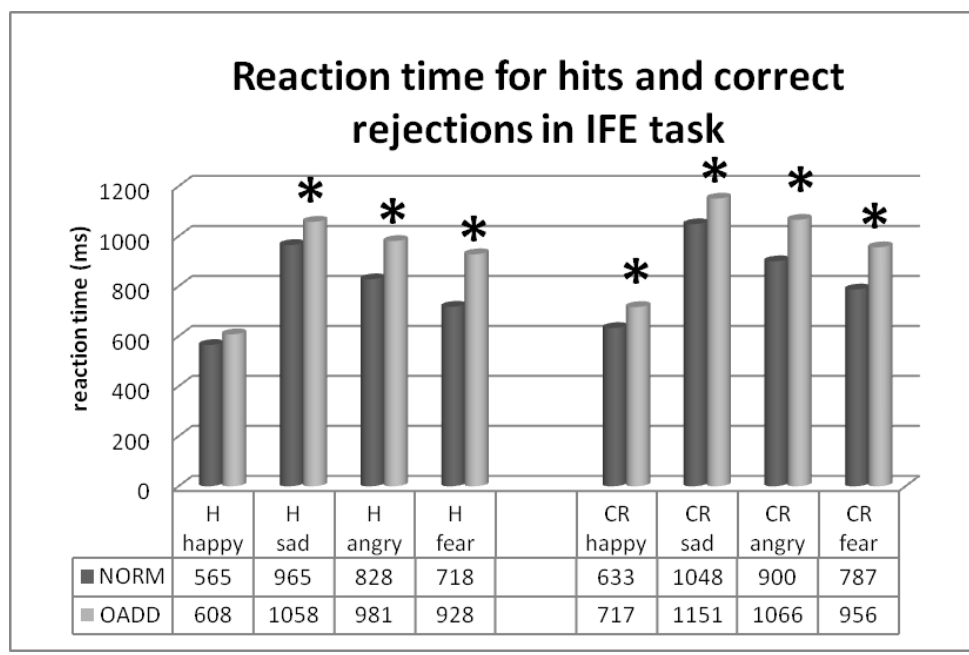

Source: Author

Figure 11. Variation of $R T$ during IFE (H=hits, CR=correct rejections, $S D=$ standard deviation, $\left.{ }^{*} p<0.05\right)$

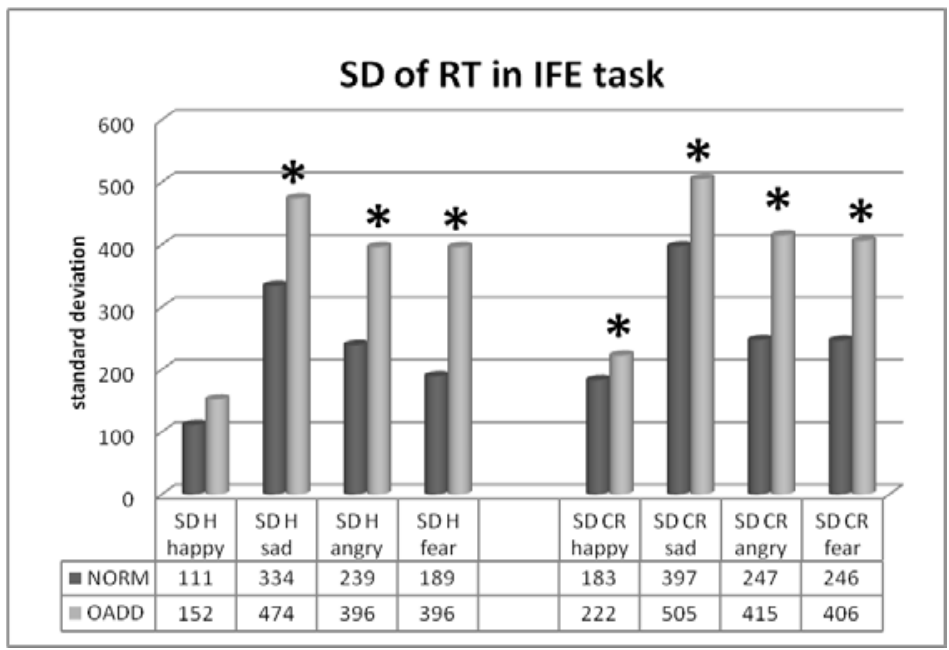

Source: Author

It has also been shown that differences in performance quality increase with task complication and duration. This objectively confirms the fact that with the work overload the attention is diminishing. 
Markovska Simoska S. et al.: Organizational attention deficit as sustainability...

Initially, as Response indicator of PSR framework, the neurofeedback training to increase the sensory-motor (SMR) EEG rhythm $(12-15 \mathrm{~Hz})$ and at the same time to inhibit the activity in the theta range $(4-8 \mathrm{~Hz})$ was performed. After that, specific training adapted to the subject subtype is applied. The treatment comprised 40 sessions, each 45-minutes duration, two times per week.

Table 2 shows the decrease of the amplitude of theta waves, the increase of the amplitude of beta waves, as well as the changes of theta/beta ratio obtained with neurofeedback training. In addition, changes in brain-rate as a spectrum shift indicator are displayed.

Table 2. Changes of neurofeedback parameters before and after training

\begin{tabular}{lcccc}
\hline Parameter & $\begin{array}{l}\text { before NF } \\
(\mu \mathrm{V})\end{array}$ & $\begin{array}{l}\text { after } N F \\
(\mu \mathrm{V})\end{array}$ & t-test & Significance \\
\hline $\begin{array}{l}\text { Beta brain } \\
\text { waves }\end{array}$ & $5.47 \pm 1.56$ & $6.98 \pm 1.31$ & 2.91 & $\mathrm{p}<0.01$ \\
$\begin{array}{l}\text { Theta brain } \\
\text { waves }\end{array}$ & $19.40 \pm 2.43$ & $15.82 \pm 2.46$ & 3.93 & $\mathrm{p}<0.001$ \\
$\begin{array}{l}\text { Theta/beta ratio } \\
\text { Brain rate }\end{array}$ & $3.83 \pm 0.94$ & $2.37 \pm 1.04$ & 2.42 & $\mathrm{p}<0.01$ \\
\hline
\end{tabular}

Source: Author

\section{Conclusion}

This approach represents a new perspective in social psychophysiology and expands the potential applications of ANT and neurofeedback methodology. Neuropsychological testing has been shown to provide features that can be used as powerful tool for assessing the location of dysfunction in OADD population.

The OADD group showed a greater response time and larger variability of reaction time than the control group, with some significant difference in error types. It has also been shown that differences in performance quality increase with task complication and duration. Accordingly, the OADD group showed more difficulties of dealing with complexity tasks. Improvements of attention span have been obtained through application of neurofeedback methodology.

In the future we planned to work with the population at risk, in particular the employees who work on the responsible and leading functions. We hope that this study will contribute to the looking of the ISD from another perspective, for the mental wellbeing of the population and consequently to the economic dimension of sustainable development. 
Markovska Simoska S. et al.: Organizational attention deficit as sustainability...

\section{References}

Barkley, R. A. (1998). Attention-deficit hyperactivity disorder: A handbook for diagnosis and treatment. New York: Guildford Press.

Davenport, H.T., Beck, C. J. (2001). The Attention Economy, Harvard Business School Press, Boston, Massachusetts.

De Sonneville, L.M.J. (1999). Amsterdam Neuropsychological Tasks: A computeraided assessment program. In: B.P.L.M. den Brinker, P.J. Beek, A.N. Brand, F.J. Maarse \& L.J.M. Mulder (Eds.), Cognitive ergonomics, clinical assessment and computer-assisted learning:Computers in psychology (Vol. 6, pp. 87-203). Lisse: Swets \& Zeitlinger.

Fetaji, B., Pop-Jordanova, N., Zorcec, T. \& Markovska, S. (2007). Measuring Elearning Effectiveness Through Testing E-content and Attention Correlation. In G. Richards (Ed.), Proceedings of World Conference on E-Learning in Corporate, Government, Healthcare, and Higher Education (pp. 293-298). Chesapeake, VA: AACE.

IAEA-IEA (2001). Indicators for Sustainable Energy Development, Joint IAEA and IEA Contribution to CSD-9, New York.

Kropotov JD. (2009). Quantitative EEG, event-related potentials and neurotherapy, Elsevier Inc.

National Research Council (1999). Our common journey, National Academy Press, Washington DC.

Pop-Jordanov, J. (2003). Indicators for Sustainable Energy Development from a Negentropic Perspective, Original Paper, Clean Techn. Environ. Policy 5, pp. 273-278; Published also in (2004): Technological Choices for Sustainability, (Sikdar, S.K., Glavic, P., Jain, R., Editors), Springer, pp. 305-316.

Pop-Jordanov, J., Markovska, N., Pop-Jordanova, N., Simoska, S. (2004). Occupational Entropy and Mind Indicators for Sustainable Energy Development, International Journal of Green Energy, Vol.1, No.3, pp. 327-335.

Pop-Jordanova, N., Markovska-Simoska S., Zorcec, T. (2005). Neurofeedback Treatment of Children with Attention Deficit Hyperactivity Disorder, MASA Contributions, Sec. Biol. Med. Sci., XXVI 1, pp. 71-80. 